\title{
Seed dispersal by fruit bats in Colombia generates ecosystem services
}

\author{
Tatiana Enríquez-Acevedo $^{1}$ (D) $\cdot$ Jairo Pérez-Torres $^{2}$ (D) $\cdot$ Cesar Ruiz-Agudelo $^{3} \cdot$ Andres Suarez $^{4,5}$ (D) \\ Accepted: 8 October 2020 / Published online: 16 November 2020 \\ (C) INRAE and Springer-Verlag France SAS, part of Springer Nature 2020
}

\begin{abstract}
When fruit bats forage, they serve an important ecological function, such as seed dispersal. Although several authors have approached the significance of bats in generating ecosystem services, there is a gap in understanding the importance of the seed dispersal by fruit bats for ecosystems and society. To fill this gap, we considered different components, such as ecosystem service drivers, functional ecosystem services, structural ecosystem services, and ecosystem services to humans. By taking two agroecosystems from the Colombian Andean region (mixed crops and extensive livestock) as the study cases, the following methodological approach was applied: (i) sampling of frugivorous bats (driver) present in the agroecosystems; (ii) identification of plants dispersed by bats (functional ecosystem services) in each agroecosystem; (iii) identification of the uses given to the plants spread (ecosystem services to humans). Finally, the plants spread by bats were considered drivers for soil fertility as well. In line of this, this research is the first in proposing a "causality chain approach" regarding the generation of ecosystem services by focusing on bat-dispersed plants. The research highlights that the diversity in frugivorous bats, the plants spread by bats, and the number of uses made of these plants were higher in mixed crops.
\end{abstract}

Keywords Functional diversity $\cdot$ Farms $\cdot$ Driver $\cdot$ Mixed crops $\cdot$ Livestock

\section{Introduction}

There is much evidence to support that ecosystem services (ES) and agroecosystems interact strongly. On the one hand, ecosystem services boost agricultural productivity (Dale and Polasky 2007; Classen et al. 2014) and, on the other, agroecosystems provide both ES and trade-offs (Chabert and Sarthou 2020; Suarez 2012; Raudsepp-Hearne et al. 2010). Some biodiversity elements play a prominent role within this two-way interaction in promoting ecological functions, which bring on improved productivity and yields in agriculture. Some examples are beneficial ecological functions of arthropods (Isaacs et al. 2009), birds, and bats (Maas et al. 2013; Triplett et al. 2012).

The quintessential research provided by Kunz et al. (2011) highlights the importance of bats in seed dispersal, pollination, and pest control, while Boyles et al. (2011) call for the attention to the economic importance of bats in agriculture. In this

Supplementary Information The online version of this article (https:// doi.org/10.1007/s13593-020-00645-0) contains supplementary material, which is available to authorized users.

Andres Suarez

asagudelo88@gmail.com

Tatiana Enríquez-Acevedo

tatianaenriquez@corpocaldas.gov.co

Jairo Pérez-Torres

jaiperez@javeriana.edu.co

Cesar Ruiz-Agudelo

cesara.ruiza@utadeo.edu.co
1 Research Group in Natural Resources and Environment (GIRNMAC), Corporación Autónoma Regional de CaldasCORPOCALDAS, Manizales, Colombia

2 Department of Biology (UNESIS), Pontificia Universidad Javeriana, Bogotá, Colombia

3 Doctoral Program in Environmental Sciences and Sustainability, Universidad Jorge Tadeo Lozano, Bogotá, Colombia

4 Department of Civil and Environmental, Universidad de la Costa, Barranquilla, Colombia

5 Research Center in Environment and Development (CIMAD), Universidad de Manizales, Manizales, Colombia 
sense, several types of research point out the importance of bats for agroecosystems. For instance, the movements of (insectivorous) bats are associated with their predation pressure on insects (Medellín et al. 2017) and pest suppression (Kemp et al. 2019); on the other hand, (frugivorous) bats promote seed dispersal (Muscarella and Fleming 2007; Kunz et al. 2011; García-Morales et al. 2012) and pollination (Winfree et al. 2011; Ghanem and Voigt 2012).

Although some studies sustain that specific agricultural activities promote bat presence (Heim et al. 2017; Park 2015; Olimpi and Philpott 2018; Rodríguez-San Pedro et al. 2018), the generality of agricultural systems affects their population and the functions they provide. Some researchers have argued that the type of agroecosystem affects bat species diversity (lower in monocultures and higher in polycultures) (Syafiq et al. 2016). Therefore, some authors point to the necessity of maintaining natural areas for bats' sustenance (Davidai et al. 2015): the loss of their habitat causes a reduction in bat-dispersed plant richness, which entails adverse effects on an ecosystem's functioning (Laurindo et al. 2019).

Ecosystem service valuation has the potential to stimulate the efficient use of resources (Wainger et al. 2010). In this sense, several approaches have sought to understand the value (particularly the economic value) of bats' ecosystem services (c.f. Ghanem and Voigt 2012; Kunz et al. 2011). Some examples found in the literature are those that highlight the economic value of bats because they prey on pests in macadamia (Taylor et al. 2018), corn (Maine and Boyles 2015), or cotton (Wiederholt et al. 2017; Federico et al. 2008; Cleveland et al. 2006) and even their importance for food security (Wanger et al. 2014). Furthermore, some studies have found evidence of bats' economic contributions for tourism (Bagstad and Wiederholt 2013). Also, some studies have sought to identify bats' ecological value in ES provision through the functional diversity approach (Barbaro et al. 2019; Sánchez 2017; García-Morales et al. 2016; Saldaña-Vázquez et al. 2015).

Scholars have also acknowledged the importance of seed dispersal for forest regeneration and plant succession (Horsley et al. 2015; García-Morales et al. 2012; Kunz et al. 2011). However, the literature has failed to include the benefits the seed dispersal process provided to the ecosystems and society. Some authors have progressed in linking the functional diversity of trees with bats as promoters of ES (Oliveira et al. 2020); however, the research has fallen short in providing an integrated valuation and understanding of the ES plants dispersed by bats. Valuing the benefits provided by the plants dispersed by bats is very important since these plants have essential implications in the restoration of ecosystems, as most of them are pioneer species (Cely-Gómez and Castillo-Figueroa 2019) that help colonize disrupted forest areas (Cortés-Delgado and Pérez-Torres 2011; Galindo-González 2005; García et al. 2000). Therefore, this research posited a "causality chain" approach regarding the generation of ecosystem services, and it focuses on bat-dispersed plants as outstanding precursors in two agroecosystems (Fig. 1).

For the analysis, we considered different links in the ES causality chain (Table 1; Fig. 2), i.e., ecosystem services drivers, functional ES, structural ES, and ES to humans. This approach lets us understand the role of bat-dispersed seeds in the promotion of ES. It is noted that they fit into the ecological domain as the drivers of functional ESs' natural dynamics. On the other hand, structural ecosystem services could fit into ecological and social domains since humans promote landscape characteristics useful for the drivers. Finally, the ES for humans fits into humans' domain, given that humans directly benefit therefrom by using the plants dispersed.

Figure 2 proffers further details regarding the causality chain approach, as it illustrates habitats and plants (structural ES) with singular characteristics that foster some of the species that act as drivers of ecosystem services (bats). These species develop functional ecosystem services such as seed dispersal due to their natural behavior (e.g., foraging). This functionality then promotes the maintenance and development of structural ES by sustaining the ecosystem's structure and diversity, both natural and transformed landscapes that attract the driver species that promote functional ecosystem service again (positive feedback loop). This approach considered that plants (and their functional traits) dispersed by frugivorous bats act as drivers of soil fertility because of the resulting ecosystem processes, namely, decomposition, cycling of nutrients, and accumulation of organic matter in the soil.

\section{Methods}

\subsection{Study area}

The La Vieja River basin represents an area of vital importance for the Colombian economy due to its strategic location and its intense economic activity, where livestock and mixed crops have become the new reality of the basin (Fig. 3). Currently, the use most made of the land is for protection (32.01\%), followed by livestock (pastures) with $31.09 \%$, agricultural purposes with $24.11 \%$, combined uses (mosaics) with $6.43 \%$, and forestry production with $1.65 \%$ (CRQ et al. 2018). Regarding the livestock systems of the La Vieja's basin, it is common to find large areas of land converted to pastures dedicated to the sustenance of livestock, with little areas remaining for natural habitat, except for some fragments of forest, isolated trees in paddocks, and riparian forests (Rodríguez et al. 2009). There is also the presence of small farms dedicated to intensive livestock (milk production), which is characterized by amply modifying the habitat under the principles of obtaining the maximum benefit in the shortest possible time, concentrating the means of production, 
Fig. 1 a Mixed crop agroecosystem and $\mathbf{b}$ extensive livestock agroecosystem
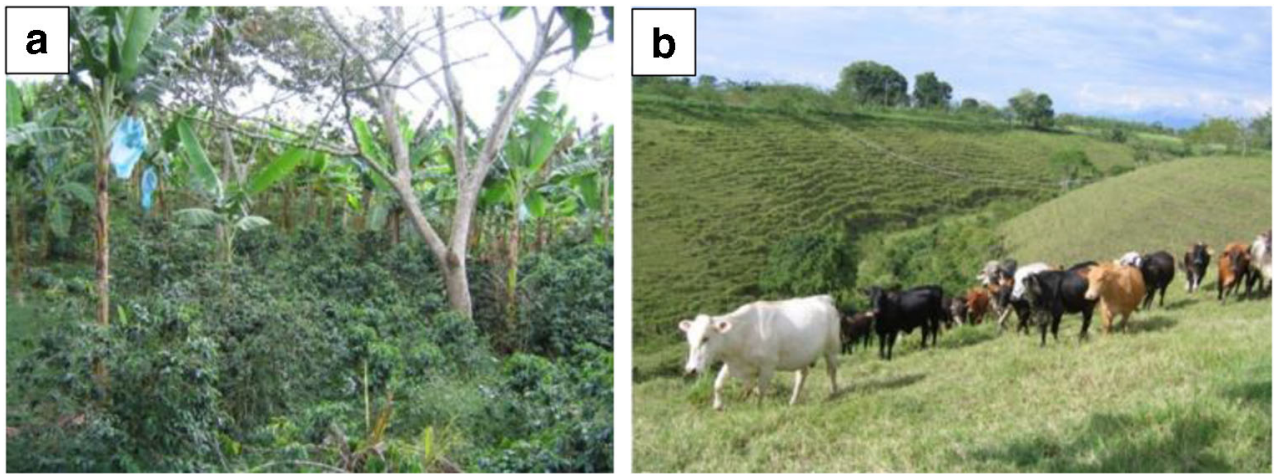

and mechanizing and streamlining processes to increase production (Zorita 2003).

On the other hand, mixed crops range from traditional production, using natural shade and native and structurally diverse species, to the modern "technical" version or sun coffee with little or no shade that makes significant use of pesticides and fertilizers (Znajda 2000). Coffee plantations with shady trees contain high biodiversity levels compared to forests (Perfecto and Armbrecht 2003) and reduce edge effects in montane forests (Santos-Barrera and Urbina-Cardona 2011).

This research was carried out in two-stage fieldwork. In the first one, we analyzed socioeconomic (uses given to plants dispersed by bats) and biological aspects (presence of bat species and plant species dispersed) in ten farms representative of extensive livestock (ELI) and mixed crops (MC) agroecosystems (five per agroecosystem) (see Supplementary material S1). We selected two farms representing each agroecosystem during the second stage to analyze the causality chain related to bat-dispersed seeds. We selected these farms because they represent each agroecosystem and represent the most extensive data and previous studies, such as degree projects and technical report. The farms are located in the municipalities of Quimbaya and Alcala, respectively. Quimbaya is located at an altitude of 1339 m.a.s.l in the department of Quindío and has a mean annual temperature of $19^{\circ} \mathrm{C}$ and mean precipitation of $1900 \mathrm{~mm}$. The farm La Floresta was chosen because it is representative of ELI. Alcala is located in Valle del Cauca at an altitude of 1290 m.a.s.l and presents a mean annual temperature of $21.6{ }^{\circ} \mathrm{C}$ and mean precipitation amounting to $2600 \mathrm{~mm}$. El Topacio, in Alcala, Valle del Cauca, was selected because it represents MC.

\subsection{Research approach}

This research was part of the megaproject entitled "Valoración de Bienes y Servicios ambientales de la Biodiversidad para el desarrollo sostenible de paisajes rurales colombianos, Complejo Ecoregional Andes del Norte (Valuation of biodiversity's goods and services for the sustainable development of Colombian rural landscapes: Eco-regional complex of Andes del Nortes CEAN per its acronym in Spanish)" by the Centro de Investigaciones en Biodiversidad y Recursos Genéticos (Research Center on Biodiversity and Genetic Resources - CIEBREG per its acronym in Spanish). The project consisted of several studies related to microorganisms, macroinvertebrates, vertebrates, and flora; likewise, the

Table 1 Descriptions of the links in the causality chain approach

\begin{tabular}{|c|c|c|c|}
\hline Concept & Description & Example & Domain \\
\hline Driver & $\begin{array}{l}\text { Species that promote interactions between } \\
\text { functional and structural ecosystem services }\end{array}$ & $\begin{array}{l}\text { Frugivorous bats } \\
\text { Plant species (chiropterochory } \\
\quad \text { dependent) }\end{array}$ & Ecological domain \\
\hline $\begin{array}{l}\text { Functional ecosystem } \\
\text { services }\end{array}$ & $\begin{array}{l}\text { Resulted from the role that the driver performs } \\
\text { in the ecosystem }\end{array}$ & Seed dispersal & Ecological domain \\
\hline $\begin{array}{l}\text { Structural ecosystem } \\
\text { services }\end{array}$ & $\begin{array}{l}\text { Provided by the ecosystems with different levels } \\
\text { of transformation which allow the driver's } \\
\text { functionality }\end{array}$ & $\begin{array}{l}\text { Crop structure } \\
\text { Livestock system structure }\end{array}$ & $\begin{array}{l}\text { Ecological domain/human } \\
\text { domain }\end{array}$ \\
\hline $\begin{array}{l}\text { Ecosystem services to } \\
\text { humans }\end{array}$ & Benefits that humans enjoy directly & $\begin{array}{l}\text { Medicinal plants } \\
\text { Timber } \\
\text { Firewood } \\
\text { Food }\end{array}$ & Human domain \\
\hline
\end{tabular}


Fig. 2 Research approach

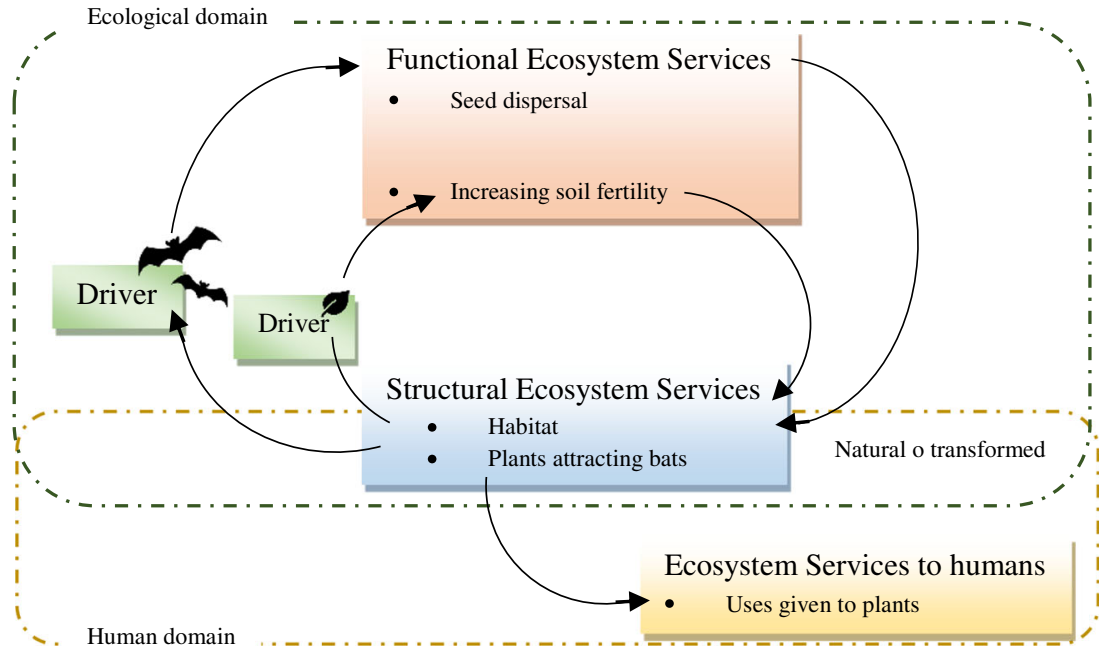

relationship between nature, agroecosystems, and social organization forms within the farms at La Vieja River's basin was addressed. Within the vertebrates' group, researchers from the Pontificia Universidad Javeriana's Laboratory of Functional Ecology made progress in studying bats. In essence, their studies considered the following aspects: the presence of species, diets, reproductive states, potential dispersal, and germination tests of seeds consumed by fruit bats.

According to this study's approach, the aim was to understand the ES causality chain in two agroecosystems and, to this end, we followed the steps: (i) identification of the frugivorous bats (driver) present in the agroecosystems; (ii) identification of the plants dispersed by bats (functional ES) in each system; (iii) highlighting of the ultimate ecosystem services used by the productive systems' managers. Finally, plants were analyzed as drivers and precursors of soil fertility.

\subsubsection{Identification of frugivorous bats present in the productive systems}

In this context, it took 12 field trips (every 2 months) to identify and determine the types of frugivorous bats present in two farms' agroecosystems regarding the ELI and MC productive

Fig. 3 The study area
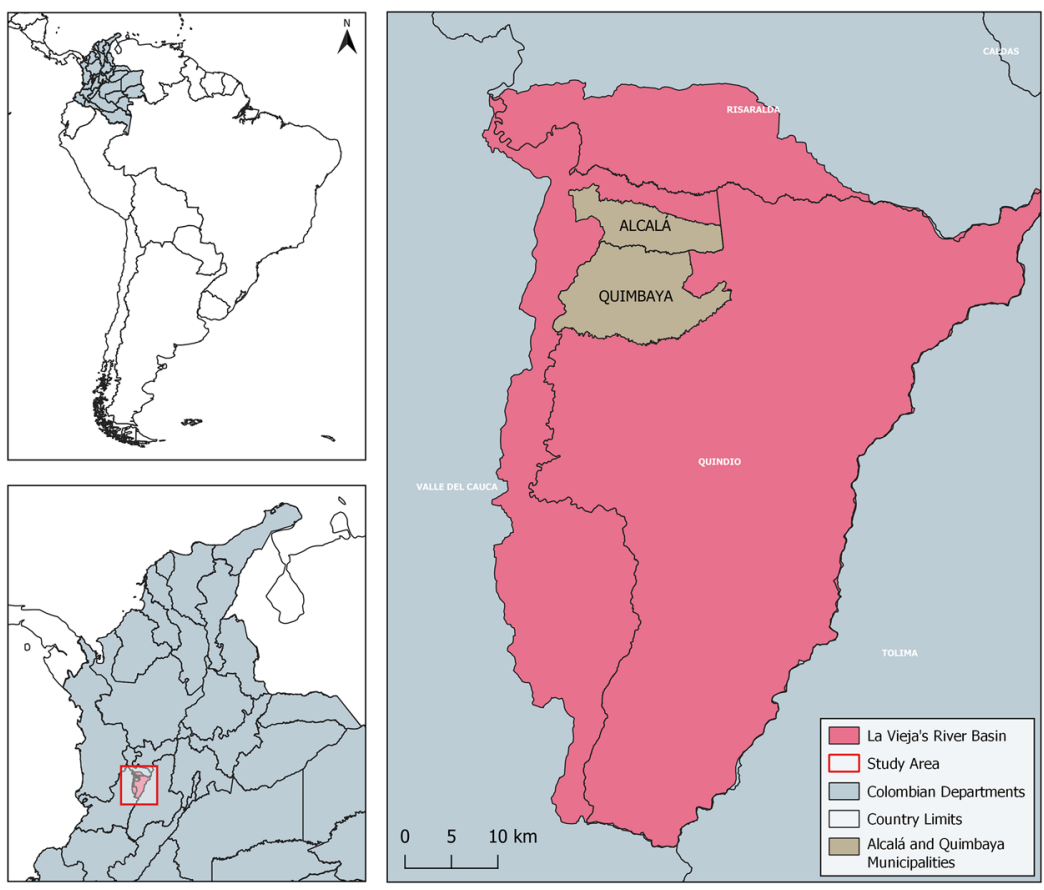
systems. The functional ecology group used 20 mist nets $(3 \mathrm{~m} \times 2 \mathrm{~m})$ located at two different heights $(0-5$ and $>5 \mathrm{~m})$. The group sampled the bats during 3-4 consecutive nights and settled nets for $12 \mathrm{~h}(18: 00-06: 00 \mathrm{~h})$. After that, they obtained the sample of fruit bat species present in each system.

\subsubsection{Identification of plants dispersed by fruit bats in each system}

The study followed two approaches to identify the plants dispersed by bats: on the one hand, as we selected an area rich in preliminary data, abundant information was gathered through secondary sources. The analysis focused on identifying the plants that attract bats according to previous research in the study area (Méndez and Calle 2010; Pérez-Torres et al. 2009; Méndez and Calle 2007). On the other hand, to identify the seeds frugivorous bats disperse, the functional ecology group collected the sampled bats in cloth bags to obtain fecal and stomach content samples. In-laboratory seed germination determined the plant species of the seeds in the fecal samples (seeds were placed in Petri dishes near a window to receive indirect light; the temperature varied between 21 and $23{ }^{\circ} \mathrm{C}$; the Petri dishes were checked every day and watered with distilled water) (Bedoya-Osorio 2009; Gómez-Junco 2008).

\subsubsection{Ecosystem services used by the production systems' managers}

To analyze the ES provided by the plants spread by frugivorous bats, we analyzed their potential and current uses in each agroecosystem. The potential uses were identified through a literature review, while the current uses were so through a questionnaire applied to the agroecosystems' managers. The first approach created a synthesis matrix from bibliographic information on frugivorous bat-spread plants' potential uses in both production systems. Later on, their uses were categorized, and the plants organized to select those with the most uses and that the evidence, or the literature, showed had been dispersed by fruit bats. In the second approach, surveys were applied to identify the current uses given by the respondents. The surveys were applied to 10 farmers (five in each agroecosystem).

\subsubsection{Plants as drivers and precursors of soil fertility}

The analysis was built on the functional diversity approach proposed by Casanoves et al. (2011) to assess soil fertility from plants spread by bats. To this end, the following considerations were observed: (a) a detailed description of the plants, (b) the production systems' extrinsic ecological characteristics, and (c) the data on the abundance of the species. Instead of comparing soil fertility in the two agroecosystems, the analysis used this approach to highlight the importance of the plants that bats scatter in soil fertility in general.

A detailed description of the plants This research protocol's starting point differs from the traditional one where species are typically selected using abundance as the go-to criterion (Cornelissen et al. 2003). In this case, the initial filter was that fruit bats had dispersed the plants in the study area, and the second is the number of current and potential uses of these plants. The abundance parameter became useful when estimating the influence of plants on the service. The measurements were not carried out in the field but through bibliographic references.

For the species identified with the most uses, descriptive sheets were created with necessary information such as the production system where the plants are present and evidence on each species throughout the literature or directly in fecal matter samples. A description of the species and their common name were included: geographical origin, the number of currents, potential uses, and threat category. In addition to the above, the study reviewed the literature containing the following 16 functional traits for each plant: (a) successional state, (b) habitat, (c) maximum height, (d) architecture, (e) foliar phenology, (f) type of fruit, (g) maximum size of the fruit, (h) seed size, (i) leaf area, (j) leaf size, (k) leaf decomposition (difficult-to-find data that was replaced by leaf hardness), (l) leaf type, (m) wood density, (n) diameter at chest height, (o) dispersing agent and root. Likewise, other essential traits, such as functionality as forage and commercial crops, were considered.

Once the sixteen functional traits per plant had been reviewed, the analysis moved on to identify the four functional traits that promote soil fertility as an ecosystem service: (i) foliar phenology, (ii) wood density, (iii) leaf size, and (iv) leaf type. The analysis included these traits because they influence soil fertility (Cornelissen et al. 2003; Casanoves et al. 2011) and because we were able to find more secondary information on these traits. The functional variables were transformed into numerical variables to analyze the data (Table 2).

The functional types of plants (FTP) were identified through a posteriori method (Casanoves et al. 2011) based on collecting information on a set of functional traits associated with the ecosystem service of interest while observing them. The result is a species-grouping dendrogram built in the statistical program InfoStat.

According to Casanoves et al. (2011), this general statistical procedure was followed:

- For the identification of FTPs, a hierarchical classification based on cluster analysis techniques was carried out, and a measure of distance or similarity was set for each sampled unit's functional features. 
Table 2 Variable transformation

\begin{tabular}{ll}
\hline Binary variables (presence/absence) & Qualitative variables (ordinal) \\
\hline $\begin{array}{l}\text { Leaf type } \\
(\text { coriaceous }=1, \text { non-coriaceous }=0)\end{array}$ & $\begin{array}{c}\text { Wood density } \\
(\text { does not apply }=0, \text { very soft }=1, \text { soft }=2, \text { middle }=3)\end{array}$ \\
$\begin{array}{l}\text { Foliar phenology }(\text { evergreen }=1, \text { deciduous }=0) \\
\text { Leaf size }(\text { middle }=1, \text { big }=2, \text { very big }=3)\end{array}$ \\
\hline
\end{tabular}

- The purposes mentioned above required applying Ward's method for chaining the data, including the covariance between functional traits, which produces amply differentiated groups.

- The choice of distance measure was determined by the type of data from the selected functional traits. Thus, the matrices of $S$ species and $T$ functional ranges were analyzed, and the analyzed data were reckoned as mixed.

- The proposed Gower's distance measure was applied, whose calculation algorithm uses Euclidean distance for continuous (quantitative) variables and Jaccard's for dichotomous (qualitative) variables. The quantitative variables were standardized, unifying the metrics and scales in which the traits are expressed in order to vest all the data with the same importance.

- The FTPs were compared through contingency tables.

\section{Extrinsic ecological characteristics of the production systems} Functional traits relate to the decomposition process and that process is, in turn, influenced by three factors: the physical environment, the quantity and quality of the substrate available to decomposers, and the characteristics of the microbial community (Chapin III et al. 2002). As such, it was decided to work with the following extrinsic characteristics, according to the available information provided by CRQ et al. (2018) and the Laboratory of Soil Ecology and Tropical Fungi from the Pontificia Universidad Javeriana: temperature, humidity, $\mathrm{pH}$, precipitation, and soil compaction.

Data related to the abundance of species Through secondary information, the study considered the abundance of plant species based on the research carried out by Calle and Méndez (2009) in connection to the La Vieja River basin's flora, which contained information on inventories of arboreal and shrub vegetation (greater than $1.5 \mathrm{~m}$ in height and $2.5 \mathrm{~cm} \mathrm{DBH}$ ). Thus, Carludovica palmata, which is considered an herb, was not included in the results. The information provided by Calle and Méndez (2009) were density, relative density, frequency, relative frequency, dominance, and relative dominance, which we harnessed to obtain the importance value indexes (IVI) by species. According to Pla et al. (2012), using the abundance or relative frequency as weight is advisable. In this case, relative density was used.

\section{Results}

\subsection{Species of frugivorous bats in the two productive systems}

Three hundred seventy-four frugivorous bats belonging to 16 species of the subfamilies Stenodermatinae and Carollinae, family Phyllostomidae, were captured (Supplementary material S2). In the extensive livestock systems (Quimbaya, Quindío), 158 fruit bats from 10 species were captured, while 216 individuals from 13 species were so at the mixed crops (Alcalá, Valle del Cauca). Seven species appeared in both systems. The MC had the most particular species $(S=7)$, of which three Platyrrhinus species stand out because they were exclusive to this system.

Among the species captured, the genus Artibeus was the most representative, with $48 \%$ of the total number of individuals, followed by Carollia with $27 \%$. The most abundant species in the MC was Artibeus lituratus, followed by Carollia perspicillata and Dermanura phaeotis. The least abundant species were Chiroderma salvini, Dermanura rava, and Platyrrhinus cf albericoi, of which only one individual was captured. In the ELI, the most abundant species was Artibeus lituratus, followed by Carollia perspicillata, while the less abundant species were Dermanura rava, Carollia castanea, and Sturnira erythromos, with two individuals each.

\subsection{Plants species potentially and effectively spread by frugivorous bats in the two production systems}

The information about the plants potentially spread by frugivorous bats in the ELI and MC allowed collecting 38 species corresponding to 25 genera and 19 families (Supplementary material S3) and excluded those whose species could not be determined. Given that not all plant species were associated with a species of disperser bats, the list of plants was divided into two: plant species of which direct evidence was found through fecal samples and species present in the area that, 
according to the literature, are spread by the fruit bats identified. This reduced the list to 17 species of plants (Table 2).

As shown in Table 3, there was a record of 17 species of plants being dispersed by bats (14 from direct evidence and three reported in the literature) in the two productive systems (ELI and MC), of which only five families were typical in both systems: Myrtaceae, Moraceae, Piperaceae, Solanaceae, and Cecropiaceae. On the other hand, the Araceae family (Xanthosoma daguense) was exclusive to the MC, while the Cyclanthaceae (Carlodovica palmata) and Anacardiaceae (Anacardium excelsum) families were exclusive to the ELI. There was bibliographic evidence of three plant species being dispersed by fruit bats, of which this study selected the species with two or more reports in the bibliography.

\subsection{Uses given to the plants spread by frugivorous bats}

A synthesis matrix was created from the bibliographic information on the potential uses of the 38 species of plants potentially dispersed by frugivorous bats in both production systems, which yielded 21 categories of uses (Supplementary material S4) and 186 single uses for all the plants in total. Eight plant species presented the highest number of uses. The highest number of potential uses was for the species Anacardium excelsum with 15 uses, followed by Psidium guajava with 13.

A survey applied to each production system found the uses given to the dispersed plants. Regarding the ELI system, ten different uses, which correspond to 6 categories of use (direct ecosystem services), were predominantly given to the Psidium guajava species, while no uses were found for Piper aduncum (Table 4, a. Extensive livestock). On the other hand, the MC system uses plant species in 24 different ways, corresponding to 9 categories, where the uses given to Psidium guajava predominated, while Anacardium excelsum went unused (Table 4, b. Mixed crops).

Psidium guajava and Carludovica palmata are the species with the most uses given by the agroecosystems under study. Species such as Anacardium excelsum have many more potential uses than what the ELI production system currently uses it for, namely, as shade for cattle (Supplementary material S4).

Out of 13 possible uses for Psidium guajava (Supplementary material S4), ELI systems make three different uses of the plant (human food, animal food, and medicine), whereas MC systems make six uses of it (human food, wood, firewood, living fences, material for crafts, and medicinal). Typical uses include human food since the fruit is used for self-consumption on farms and medicinal purposes, especially for stomach malaise. Concerning Piper aduncum, the analysis found that ELI farms perceived it as a problematic weed to eradicate. Therefore, there is no use thereof on record. On the other hand, $\mathrm{MC}$ farms recorded using the species for medicinal purposes (for headaches and urinary system malaise) and firewood. Farmers were asked about the Ficus species as a single category due to the respondents' difficulty in telling them apart, and the survey found that while ELI systems do not see the species as more than food for wildlife, MC systems regard it as essential to attract wildlife and used it as a source of wood and firewood. Finally, Carludoviva palmata is used more amply in MC systems. In this context, the respondents' knowledge of each agroecosystem provided some differences between plants' uses.

\subsection{Plants as a precursor of soil fertility}

\subsubsection{Description of plants}

For the study, a total of two functional types of plants (PFT) was obtained: the first one consists of six similar species of Ficus sp. as per the selected features. On the other hand, we identified a more remarkable similarity between Anacardium excelsum and the Ficus sp. group, while Psidium guajava fell outside the group mainly due to differences in wood density. The second PFT consists of the species known as Piper aduncum and Carludovica palmata, which coincided with three functional features (foliar phenology, leaf type, and wood density). Leaf size did not affect the groups' classification and separation processes since the different leaf sizes were found for both PFTs.

Using contingency table analysis (Table 5), the most useful variables for the separation of groups showed significant associations $(p<0.05)$ between foliar phenology and the type of leaf, followed by wood density. PFT1 includes deciduous species, with leathery leaves and species with different wood densities; strategy: secondary arboreal species, different types of fruits, predominating in the environment, and large fruits. They grow less than those with lower density_medium and high heights. PFT2 contains evergreen species with non-leathery leaves and the absence of wood density; strategy: pioneer herbaceous or shrub species; fruit type grouped berries, small fruits, fast growth, and low height.

\subsubsection{Extrinsic ecological characteristics of the productive systems}

The differences between agroecosystems are given not only by whether direct evidence or the literature (as differentiated earlier) found the plants to be dispersed but also by the extrinsic characteristics (Table 6). In this vein, variables such as temperature and $\mathrm{pH}$ were more favorable for soil fertility in the ELI systems, whereas variables such as humidity, precipitation, and soil compaction were more favorable in the MC. 


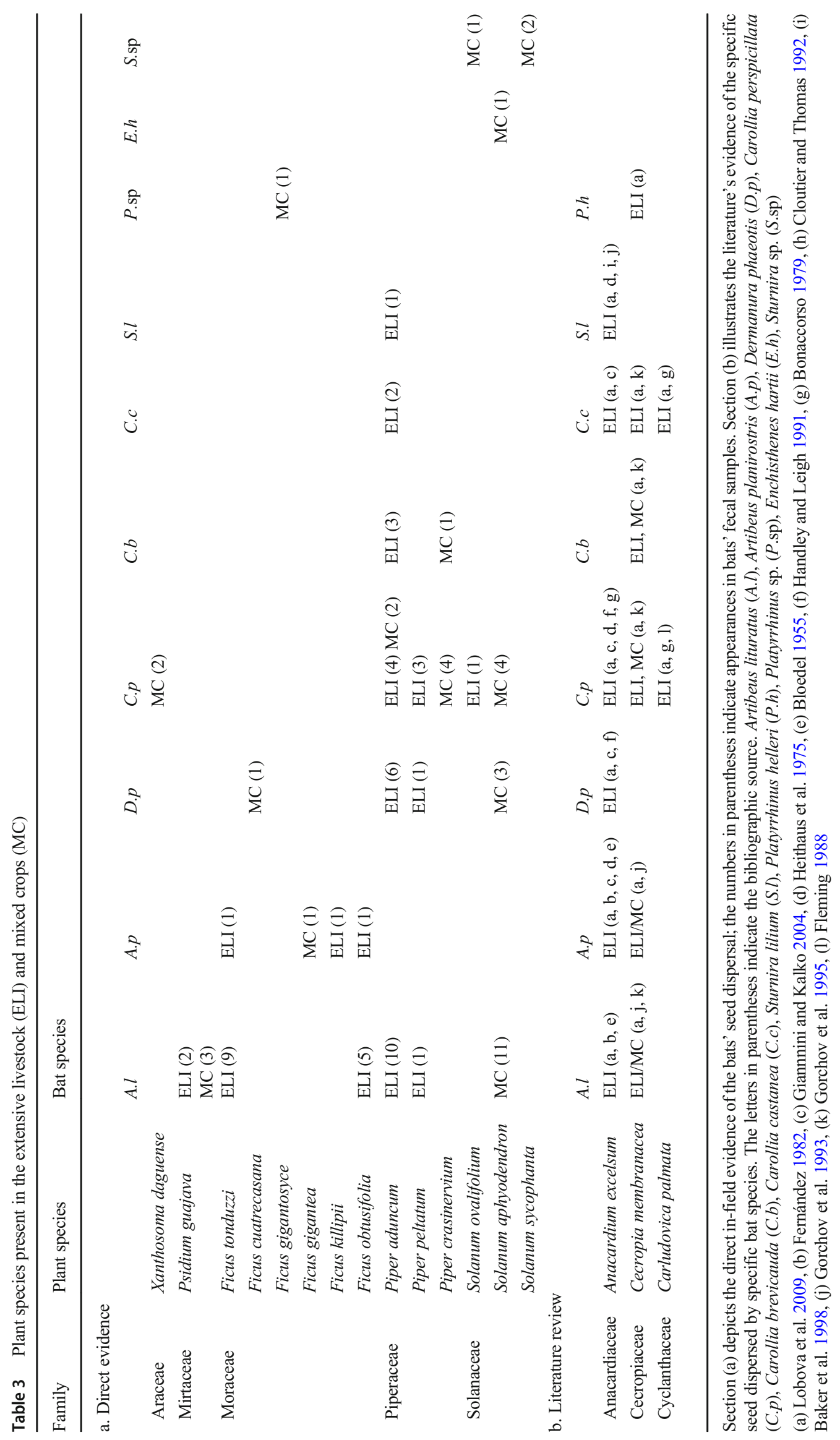


Table 4 Dispersed plants and uses given both in ELI and MC

\begin{tabular}{|c|c|c|c|c|c|}
\hline \multirow[t]{2}{*}{ Family } & \multirow[t]{2}{*}{ Species } & \multirow[t]{2}{*}{ Uses } & \multicolumn{3}{|c|}{ Kind of uses and ecosystem services } \\
\hline & & & Provision & Regulating & Cultural \\
\hline \multicolumn{6}{|c|}{ a. Extensive livestock } \\
\hline Anacardiaceae & $\begin{array}{c}\text { Anacardium } \\
\text { excelsum }\end{array}$ & 1 & & Shade & \\
\hline Myrtaceae & Psidium guajava & 3 & $\begin{array}{l}\text { Human food, animal } \\
\text { food, medicine }\end{array}$ & & \\
\hline Piperaceae & Piper aduncum & 0 & & & \\
\hline Moraceae & Ficus tonduzzi & 1 & Animal food & & \\
\hline Cyclanthaceae & $\begin{array}{c}\text { Carludovica } \\
\text { palmata }\end{array}$ & 2 & & $\begin{array}{l}\text { Basin } \\
\text { protection }\end{array}$ & Handicrafts \\
\hline Moraceae & Ficus gigantosyce & 1 & Animal food & & \\
\hline Moraceae & $\begin{array}{l}\text { Ficus } \\
\quad \text { cuatrecasana }\end{array}$ & 1 & Animal food & & \\
\hline \multirow[t]{2}{*}{ Moraceae } & Ficus obtusifolia & 1 & Animal food & & \\
\hline & Total & 10 & & & \\
\hline \multicolumn{6}{|l|}{ b. Mixed crops } \\
\hline Anacardiaceae & $\begin{array}{c}\text { Anacardium } \\
\text { excelsum }\end{array}$ & 0 & & & \\
\hline Myrtaceae & Psidium guajava & 6 & $\begin{array}{l}\text { Animal food, } \\
\text { medicine, timber, } \\
\text { firewood }\end{array}$ & Living fences & Handicrafts \\
\hline Piperaceae & Piper aduncum & 2 & Medicine, firewood & & \\
\hline Moraceae & Ficus tonduzzi & 3 & Human food, timber & & Cultural use \\
\hline Cyclanthaceae & $\begin{array}{c}\text { Carludovica } \\
\text { palmata }\end{array}$ & 4 & Animal food & & $\begin{array}{l}\text { Scenic, cultural } \\
\text { use, } \\
\text { handicrafts }\end{array}$ \\
\hline Moraceae & Ficus gigantosyce & 3 & Human food, timber & & Cultural use \\
\hline Moraceae & $\begin{array}{l}\text { Ficus } \\
\quad \text { cuatrecasana }\end{array}$ & 3 & Human food, timber & & Cultural use \\
\hline \multirow[t]{2}{*}{ Moraceae } & Ficus obtusifolia & 3 & Human food, timber & & Cultural use \\
\hline & Total & 24 & & & \\
\hline
\end{tabular}

\subsubsection{Data related to species abundance}

Ficus species, as part of the Moraceae family, represent $50 \%$ of the plants bats consume that have the highest number of uses. It is also the second family with the highest importance value index in La Vieja River basin (Calle and Méndez 2009), and it is part of the FTP1. This group of species could provide an essential contribution to soil fertility, mainly on account of
Table 5 Absolute frequencies by functional type and categorized feature and result of the contingency table analysis

\begin{tabular}{llllllll}
\hline \multirow{2}{*}{ Foliar phenology } & & No. sp. & PFT1 & PFT2 & $X^{2}$ & $p$ \\
& Evergreen & 0 & 2 & 0 & 2 & 0.00 & $<0.05$ \\
& Deciduous & 1 & 6 & 6 & 0 & & \\
\multirow{5}{*}{ Leaf size type } & Middle & 1 & 2 & 1 & 1 & 0.06 & $>0.05$ \\
& Big & 2 & 5 & 5 & 0 & & \\
Wood density & Very big & 3 & 1 & 0 & 1 & & \\
& Coriaceous & 1 & 6 & 6 & 0 & 0.00 & $<0.05$ \\
& Non-coriaceous & 0 & 2 & 0 & 2 & & \\
& N/A & 0 & 2 & 0 & 2 & 0.04 & $<0.05$ \\
& Very soft & 1 & 4 & 4 & 0 & & \\
\hline
\end{tabular}


Table 6 Extrinsic characteristics in the studied agroecosystems

\begin{tabular}{|c|c|c|c|c|c|}
\hline \multirow[t]{2}{*}{ Variable } & \multirow[t]{2}{*}{ Description } & \multicolumn{2}{|l|}{ ELI } & \multicolumn{2}{|l|}{$\mathrm{MC}$} \\
\hline & & Soil & Environment & Soil & Environment \\
\hline Temperature & $\begin{array}{l}\text { It directly affects decomposition by } \\
\text { promoting microbial activity (Chapin } \\
\text { III et al. 2002). }\end{array}$ & $22{ }^{\circ} \mathrm{C}$ & $18-24{ }^{\circ} \mathrm{C}$ & $18^{\circ} \mathrm{C}$ & $12-18{ }^{\circ} \mathrm{C}$ \\
\hline Humidity & $\begin{array}{l}\text { Decomposition rates generally decline } \\
\text { when soil moisture decreases (Chapin } \\
\text { III et al. 2002). }\end{array}$ & $29 \%$ & $80 \%$ & $30 \%$ & $86 \%$ \\
\hline $\mathrm{pH}$ & $\begin{array}{l}\text { Decomposition occurs faster in neutral } \\
\text { than acidic soils (Chapin III et al. 2002). }\end{array}$ & 6.6 & - & 6.1 & - \\
\hline Precipitation & $\begin{array}{l}\text { It influences litterfall (Enríquez-Acevedo } \\
\text { 2012) and exerts an effect on } \\
\text { environmental factors such as soil } \\
\text { temperature, humidity, and pH, which } \\
\text { significantly influence microbial } \\
\text { activity. }\end{array}$ & - & $1900 \mathrm{~mm}$ & - & $2600 \mathrm{~mm}$ \\
\hline $\begin{array}{l}\text { Soil } \\
\text { compac- } \\
\text { tion }\end{array}$ & $\begin{array}{l}\text { Livestock stamping produces soil } \\
\text { compaction (CRQ et al. 2018), limiting } \\
\text { oxygen availability for decomposition } \\
\text { (Chapin III et al. 2002). }\end{array}$ & \multicolumn{2}{|c|}{$\begin{array}{l}\text { Compacted soils for } \\
\text { livestock stamping }\end{array}$} & \multicolumn{2}{|c|}{ Less compact soil } \\
\hline
\end{tabular}

their foliar phenology characteristics. Additionally, by distribution, Ficus species can be found in either of the two agroecosystems (Table 7).

\section{Discussion}

This study is the first to introduce the concepts of structural $\mathrm{ES}$, functional ES, and ecosystem services' drivers into the analysis of bat seed dispersal in two agroecosystems, namely ELI and MC. Therefore, this research represents a novel indirect valuation approach of a complicated functional ES. The causality chain approach sheds light on the ecological dynamics related to seed dispersal (ecological domain), and then it analyzed the human dimension through the social uses given to the plants dispersed by bats (germinated seeds). Such an indirect approach emphasizes the uses of dispersal-produced plants and the benefits (ES to humans) these plants provide to inhabitants' productive systems. Different ES valuation studies related to bats have been developed; however, these have focused more on the ecological perspective (Costa et al. 2018; Ayivor et al. 2017; Ancillotto et al. 2017; LópezHoffman et al. 2017; Horsley et al. 2015) or contributions to productivity (Maas et al. 2013; Gras et al. 2016; Denmead et al. 2017). Moreover, some studies have analyzed the economic and ecological impacts of the services generated by the bats (Kunz et al. 2011); nevertheless, there is a gap in the studies that disentangled ecosystems' multiple services concerning the plants dispersed by fruit bats.

\subsection{Bat diversity in the study's production systems}

Concerning the captured individuals, 58\% were retrieved from the MC and $42 \%$ from ELI. The species abundance and richness (although not statistically significant) were found to be higher in the MC productive system. This result agrees with the studies showing lower bat species diversity in ELI pastures than in other habitats of greater structural complexity
Table 7 Relative frequency of plants in the agroecosystems

\begin{tabular}{llll}
\hline Family & Species & Agroecosystem & Relative frequency (CIVAP 2009) \\
\hline Anacardiaceae & Anacardium excelsum & ELI & 2.75 \\
Mirtaceae & Psidium guajava & ELP/MC & 1.65 \\
Piperaceae & Piper aduncum & ELI & 0.55 \\
Moraceae & Ficus tonduzzi & ELI & 0.55 \\
& Ficus gigantosyce & MC & 0.55 \\
& Ficus cuatrecasana & MC & 0.55 \\
& Ficus obtusifolia & ELI & 0.55 \\
\hline
\end{tabular}


(Estrada et al. 1993). MC systems, and specifically those of shaded coffee, have more trees. Hence, MC systems are closer to the structural complexity of the forests that provide bats with a wide variety of food resources, perch sites in the canopy, and the foraging that favors the presence of bats (Lacoeuilhe et al. 2018; Starik et al. 2018; Sosa et al. 2008; Ortegón-Martínez and Pérez Torres 2007; Perfecto and Armbrecht 2003; Estrada and Coates-Estrada 2001; Estrada et al. 1993).

Among the most abundant species (with more than 70 individuals captured), Artibeus lituratus and Carollia perspicillata were found to be the generalist species that consume fruits of both pioneer and persistent species (OleaWagner et al. 2007). However, they specialize in consuming fruits associated with successional plant species (Rivas-Rojas 2005), typical of the intervened environments (Sosa et al. 2008), thus increasing in abundance in places undergoing transformation and deforestation.

The richness in species of plants consumed by bats in MC is higher than ELI's, which agrees with the description of structural complexity and species offer provided earlier. The Piper aduncum species stands out for its high use (54\%) and consumption by many frugivorous bat species, especially Carollia perspicillata, followed by Artibeus lituratus (Table 3). Furthermore, the evidence shows these species have been effectively dispersed (Gómez-Junco 2008; BedoyaOsorio 2009), which indicates that the seed leaves the frugivorous bats' digestive tract unaltered, which coincides with Dumont's (2003) finding that bats mostly consume mature fruits and their seeds are swallowed and excreted mostly undamaged.

\subsection{Bats and ecosystem services}

Bats play an essential role in ecosystems (García-Morales et al. 2016; Vanitharani 2014; Ghanem and Voigt 2012; Kunz et al. 2011). In this line, bats are outstanding drivers regarding the generation of ES (Fig. 1). Seed dispersal by bats is a functional ES, which indirectly fosters other benefits both for the ecosystems and society. The above is essential because bats play a crucial role in the natural regeneration processes (Laurindo et al. 2019) that bring well-being to humans by using bat-dispersed plants. This study contributes additional elements to other studies like Vanitharani (2014) and Horsley et al. (2015) because this research goes beyond analyzing dispersed plants by addressing the uses given to these plants in two different contexts. As this study found and aligned with Scanlon et al. (2014), a strong relationship exists between batdispersed plants and those humans use. At a general level, and according to the respondents, it was observed that the uses given to the plants dispersed by frugivorous bats were more varied in MC (Table 4).
It is common in ELI systems to acquire goods and services outside the productive system (i.e., food, medicine, fertilizers, wood), while MC system farmers are prone to using local inputs in their production activities. The finding coincides with what Díaz et al. (2011) stated, in that farmers with subsistence-oriented productive systems see plant resources as an input to the system; wherefore, they value these components highly. On the other hand, cattle-raising owners tend to maximize benefits through the intensive and specialized use of a limited number of ecosystem services, which sustain processes and products destined for the market (Díaz et al. 2011). Thus, the respondents tend to value lowly plants' functional attributes, and it is common to find that not every species is of interest for production. Besides, some plants are considered undesirable for a production system because they fail to contribute to the system and entail additional eradication costs: this is the case of Piper aduncum.

\subsection{Plants dispersed and soil fertility}

Ecological valuation through the functional diversity approach offers a novel approach to the causal relationships between the drivers of global environmental change, biodiversity, and ecological functioning, and the essential services for human well-being that ecosystems provide (Martín-López et al. 2007). Although all components of biodiversity, from genetic organization to community scale, play essential roles in the provision of functions and services, there is evidence that suggests that functional diversity is the component that best explains the effects of biodiversity on many services essential for humans (Díaz et al. 2006).

Soil fertility was selected for the ecological assessment because it is a service with biophysical and socioeconomic influence in both agroecosystems studied, given that it supports the provision of services such as food production (Zhang et al. 2007). PFT1 was identified as the most influential in soil fertility because of its foliar phenology and because its semideciduous nature contributes litter to the soil, which is regarded among the most critical factors for the fertility of soils (Kremen 2005). Additionally, trees' effects on the ground are reduced erosion, litter-covered soil, and understory vegetation coupled with permanent organic matter, diversity by the litter's decomposition, nitrogen fixation, and the soil's improved physical characteristics. The above is due to the structure, porosity, moisture retention by the root system, and the covering of the crown, in addition to improving efficiency in the use of nutrients since trees' root systems, can intercept, absorb, and recycle the soil's nutrients, which would otherwise be lost to leaching (Pattanayak and Evan 1996).

Dominant (very abundant) plants' functional characteristics seem to be the primary influence in soil processes, rather than the number of species present (Díaz and Cabido 2001; Hooper et al. 2005). Aspects such as decomposition, and 
organic matter and nutrient consumption dynamics of soil microorganisms, and nutrient retention see a more substantial influence by dominant plants' differences in functional traits (such as leaf chemistry, or phenology) than by species diversity in the plants present (Hooper et al. 2005). The dominant species are the most critical determinants of ecosystems' properties, such as productivity, carbon sequestration, nutrient cycling, and litter quality (Pla et al. 2012).

\section{Conclusion}

This research is the first to help fill the gap in understanding how seeds spread by bats generate ES in two agroecosystems in Colombia. A novel approach to ecosystem services' causality chain stands out from this research. In this vein, bats were introduced as ES drivers that promote habitat maintenance (structural ES) through ecological functions such as seed dispersal (functional ES), which attracts bats and produces positive feedback loops. In this process, the dispersal of seeds by fruit bats contributes to another relevant functional ES, such as soil fertility supported by the plants growing from the abovementioned dispersed seeds. All these interactions could be explained from an ecological domain. Furthermore, the plants spread by bats also produce several benefits to society (ES to humans), emphasizing the human dimension of the ELI's and MC's ecological structure and functioning.

On the other hand, despite the data's inherent limitations, the results show that functional features influence soil fertility according to the dispersed plant's abundance in specific contexts. It is also noteworthy that more frugivorous bats were found in the MC systems, as well as more uses for the plants dispersed by the former. The plant species with the highest number of uses were Psidium guajava and Carludovica palmata.

Acknowledgments We want to thank Dr. Arias-Arévalo for her valuable suggestions. We thank the members of the Laboratory of Functional Ecology from the Universidad Javeriana. Also, we want to thank the peer reviewers for their valuable suggestions.

\section{Compliance with ethical standards}

Funding This research was funded by CIEBREG and supported by the Laboratory of Functional Ecology from the Universidad Javeriana.

Conflict of interest The authors declare that they have no conflict of interest.

Author Contribution C. Ruiz-Agudelo, J. Pérez-Tórres, and T. Enríquez-Acevedo: conceptualization, validation, methodology, writing-reviewing. A. Suarez: conceptualization, methodology, writing-original draft preparation. T. Enríquez-Acevedo: data curation, field research, and editing.

\section{References}

Ancillotto L, Ariano A, Nardone V, Budinski I, Rydell J, Russo D (2017) Effects of free-ranging cattle and landscape complexity on bat foraging: implications for bat conservation and livestock management. Agric Ecosyst Environ 241:54-61. https://doi.org/10.1016/j.agee. 2017.03.001

Ayivor JS, Ohemeng F, Tweneboah Lawson E, Waldman L, Leach M, Ntiamoa-Baidu Y (2017) Living with bats: the case of Ve Golokuati township in the Volta region of Ghana. J Environ Public Health 5938934:1-11. https://doi.org/10.1155/2017/5938934

Bagstad KJ, Wiederholt R (2013) Tourism values for Mexican free-tailed bat viewing. Hum Dimens Wildl 18:307-311. https://doi.org/10. 1080/10871209.2013.789573

Barbaro L, Allan E, Ampoorter E, Castagneyrol B, Charbonnier Y, De Wandeler $\mathrm{H}$ et al (2019) Biotic predictors complement models of bat and bird responses to climate and tree diversity in European forests. Proc R Soc B 286:20182193. https://doi.org/10.1098/rspb.2018. 2193

Baker HG, Baker I, Hodges SA (1998) Sugar compositions of nectars and fruits consumed by birds and bats in the tropics and subtropics. Biotropica 30:559-586. https://doi.org/10.1111/j.1744-7429.1998. tb00097.x

Bedoya-Osorio C (2009) Dispersión de semillas por el conjunto de murciélagos frugívoros en dos sistemas productivos (Ganadería extensiva y Cultivos Mixtos) en el eje cafetero, Colombia. Trabajo de grado. Pregrado en Biología. Pontificia Universidad Javeriana. Facultad de Ciencias. Departamento de Biología

Bloedel P (1955) Observations on the life histories of Panamá bats. J Mammal 36:232-235. https://doi.org/10.2307/1375881

Bonaccorso FJ (1979) Foraging and reproductive ecology in a Panamanian bat community. Bull Fla State Mus Niol Sci 24:359 408 https://ufdc.ufl.edu/AA00024888/00001

Boyles JG, Cryan PM, McCracken GF, Kunz TH (2011) Economic importance of bats in agriculture. Science 332:41-42 https://science. sciencemag.org/content $/ 332 / 6025 / 41$

Calle Z, Méndez LE (2009) Estructura y composición de la vegetación arbórea en el agropaisaje del río La Vieja. En: Valoración de la Biodiversidad en la Ecorregión del Eje Cafetero. CIEBREG. Pereira, Colombia, pp. 171-184

Casanoves F, Pla L, Rienzo JA (2011) Valoración y análisis de la diversidad funcional y su relación con los Servicios Ecosistémicos. Centro Agronómico Tropical de Investigación y Enseñanza, CATIE. Serie Técnica, Informe Técnico No. 384. http://www. nucleodiversus.org/uploads/file/Casanoves\%20et\%20al\%202011\% 20Serie\%20Tecnica\%20CATIE.pdf

Chapin FS III, Matson PA, Mooney HA (2002) Principles of ecosystem ecology. Springer-Verlag, New York, New York

Cely-Gómez MA, Castillo-Figueroa D (2019) Diet of dominant frugivorous bat species in an oil palm landscape from Colombian Llanos: implications for forest conservation and recovery. Therya 10:149 $153 \mathrm{http} / /$ www.revistas-conacyt.unam.mx/therya/index.php/ THERYA/article/view/682

Chabert A, Sarthou JP (2020) Conservation agriculture as a promising trade-off between conventional and organic agriculture in bundling ecosystem services. Agric Ecosyst Environ 292:106815. https://doi. org/10.1016/j.agee.2019.106815

Classen A, Peters MK, Ferger SW, Helbig-Bonitz M, Schmack JM, Maassen G, Schleuning M, Kalko EKV, Böhning-Gaese K, Steffan-Dewenter I (2014) Complementary ecosystem services provided by pest predators and pollinators increase quantity and quality of coffee yields. Proc R Soc B 281:20133148. https://doi.org/10. 1098/rspb.2013.3148

Cleveland CJ, Betke M, Federico P, Frank JD, Hallam TG, Horn J, López JD Jr, McCracken GF, Medellín RA, Moreno-Valdez A, Sansone 
CG, Westbrook JK, Kunz TH (2006) Economic value of the pest control service provided by Brazilian free-tailed bats in south-central Texas. Front Ecol Environ 4:238-243. https://doi.org/10.1890/ 1540-9295(2006)004[0238:EVOTPC]2.0.CO;2

Cloutier D, Thomas DW (1992) Carollia perspicillata. Mamm Species 417:1-9 https://academic.oup.com/mspecies/article/doi/10.2307/ $3504157 / 2600673$

Cornelissen JHC, Lavorel S, Garnier E, Díaz S, Buchmann N, Gurvich DE, Reich PB, Steege H, Morgan HD, Heijden MGA, Pausas JG, Poorter H (2003) A handbook of protocols for standardized and easy measurement of plant functional traits worldwide. Aust J Bot 51: 335-380 https://www.uv.es/jgpausas/papers/Cornelissen\%20et\% 20al\%202003\%20handbook.pdf

Cortés-Delgado N, Pérez-Torres J (2011) Habitat edge context and the distribution of phyllostomid bats in the Andean forest and anthropogenic matrix in Central Andes of Colombia. Biol Conserv 20: 987-999. https://doi.org/10.1007/s10531-011-0008-1

Costa WF, Ribeiro M, Saraiva AM, Imperatriz-Fonseca VL, Giannini TC (2018) Bat diversity in Carajás National Forest (Eastern Amazon) and potential impacts on ecosystem services under climate change. Biol Conserv 218:200-210. https://doi.org/10.1016/j.biocon.2017. 12.034

CRQ, CVC, CARDER et al. (2018) Actualización POMCA rio La Vieja: Plan de ordenación y manejo de la cuenca hidrográfica 2018-2032. Retrieved from: https://crq.gov.co/index.php/2016-12-28-22-26-17/ pomca

Dale VH, Polasky S (2007) Measures of the effects of agricultural practices on ecosystem services. Ecol Econ 64:286-296. https://doi.org/ 10.1016/j.ecolecon.2007.05.009

Davidai N, Westbrook JK, Lessard JP, Hallam TG, McCracken GF (2015) The importance of natural habitats to Brazilian free-tailed bats in intensive agricultural landscapes in the Winter Garden Region of Texas, United States. Biol Conserv 190:107-114. https://doi.org/10.1016/j.biocon.2015.05.015

Denmead LH, Darras K, Clough Y, Diaz P, Grass I, Hoffmann MP, Nurdiansyah F, Fardiansah R, Tscharntke T (2017) The role of ants, birds and bats for ecosystem functions and yield in oil palm plantations. Ecology 98:1945-1956. https://doi.org/10.1002/ecy.1882

Díaz S, Cabido M (2001) Vive la difference: plant functional diversity matters to ecosystem processes. Trends Ecol Evol 16:646-655. https://doi.org/10.1016/S0169-5347(01)02283-2

Díaz S, Lavorel S, Mcintyre V, Falczuk F, Casanoves DG et al (2006) Plant trait responses to grazing-a global synthesis. Glob Chang Biol 12:1-26. https://doi.org/10.1111/j.1365-2486.2006.01288.x

Díaz S, Quétier F, Cáceres D, Trainor S, Pérez-Harguindeguy N, BreHarte M, Finegan B, Peña-Claros B, Poorter L (2011) Linking functional diversity and social actor strategies in a framework for interdisciplinary analysis of nature's benefits to society. PNAS 108:895902. https://doi.org/10.1073/pnas.1017993108

Dumont ER (2003) Bats and fruit: an ecomophological approach. In Bat ecology (eds. T. H. Kunz and M. B. Fenton), pp. 398-429. University of Chicago Press, Chicago, IL

Enríquez-Acevedo T (2012) Aproximación económica y ecológica del aporte de las plantas dispersadas por murciélagos frugívoros al bienestar de los pobladores de dos sistemas productivos (cuenca del río la vieja). Trabajo de grado. Maestría en Ciencias Biológicas. Universidad Javeriana. Facultad de Ciencias. Departamento de Biología

Estrada A, Coates-Estrada R, Merrit D (1993) Bat species and abundance in tropical rain forest fragments and in agricultural habitats in Los Tuxtlas, México. Ecography 16:309-318. https://doi.org/10.1111/j. 1600-0587.1993.tb00220.x

Estrada A, Coates-Estrada R (2001) Species composition and reproductive phenology of bats in a tropical landscape at Los Tuxtlas, México. J Trop Ecol 17:627-646
Federico P, Hallam TG, McCracken GF, Purucker ST, Grant WE, Correa-Sandoval AN et al (2008) Brazilian free-tailed bats as insect pest regulators in transgenic and conventional cotton crops. Ecol Appl 18:826-837. https://doi.org/10.1890/07-0556.1

Fernández AB (1982) Murciélagos de Venezuela II: PhyllostomidaeStenodermatinae. Rev Fac Agron 12:327-352

Fleming TH (1988) The short-tailed fruit bat. University of Chicago Press, Chicago

Galindo-González J (2005) ¿Regeneración de la selva? Los murciélagos expertos en el asunto. La Ciencia y el hombre 18:37-40

García QS, Rezende JL, Aguiar LM (2000) Seed dispersal by bats in a disturbed area of Southeastern Brazil. Rev Biol Trop 48: 125-128

García-Morales RG, Chapa-Vargas L, Galindo-González J, Badano EI (2012) Seed dispersal among three different vegetation communities in the Huasteca region, Mexico, analyzed from bat feces. Acta Chiropt 14:357-367. https://doi.org/10.3161/150811012X661675

García-Morales R, Moreno CE, Badano EI, Zuria I, Galindo-González J, Rojas-Martínez AE, Ávila-Gómez ES (2016) Deforestation impacts on bat functional diversity in tropical landscapes. PLoS One 11: e0166765. https://doi.org/10.1371/journal.pone.0166765

Ghanem SJ, Voigt C (2012) Increasing awareness of ecosystem services provided by bats. In Advances in the study of behavior (Vol. 44, pp. 279-302). Academic Press

Giannnini NP, Kalko EK (2004) Trophic structure in a large assemblage of phyllostomid bats in Panamá. Oikos 105:209-220. https://doi. org/10.1111/j.0030-1299.2004.12690.x

Gómez-Junco GP (2008) Capacidad de germinación de semillas consumidas por murciélagos frugívoros y su calidad de dispersión en un bosque de cañada en un sistema de ganadería intensiva en el norte del Valle del Cauca (Colombia). Trabajo de grado. Pregrado en Biología. Pontificia Universidad Javeriana. Facultad de Ciencias. Departamento de Biología

Gorchov DL, Cornejo F, Ascorra C, Jaramillo M (1993) The role of seed dispersal in the natural regeneration of rain forest after strip-cutting in the Peruvian Amazon. Vegetation 107-108:339-349

Gorchov DL, Cornejo F, Ascorra CF (1995) Dietary overlap between frugivorous birds and bats in the Peruvian Amazon. Oikos. 74: 235-250 https://www.jstor.org/stable/3545653

Gras P, Tscharntke T, Maas B, Tjoa A, Hafsah A, Clough,Y (2016) How ants, birds and bats affect crop yield along shade gradients in tropical cacao agroforestry. J Appl Ecol 53: 953-963. https://doi.org/10. $1111 / 1365-2664.12625$

Handley C, Leigh EG (1991) Diet and food supply. pp. 147-149. In: C.O Handley Jr., D.E. Wilson \& A.L. Gardner. Demography and natural history of the common fruit bat Artibeus jamaicensis on Barro Colorado Island, Panamá. Smithsonian Institution Press, Washington, D.C.

Heim O, Lorenz L, Kramer-Schadt S, Jung K, Voigt C, Eccard JA (2017) Landscape and scale-dependent spatial niches of bats foraging above intensively used arable fields. Ecol Process 6:24. https://doi. org/10.1186/s13717-017-0091-7

Heithaus ER, Flemming TH, Opler P (1975) Foraging patterns and the resource utilization in seven species of bats in a seasonal tropical forest. Ecology. 56:841-854. https://doi.org/10.2307/1936295

Hooper DU, Chapin S, Ewel J, Hector A, Inchausti P, Lavorel S et al (2005) Effects of biodiversity on ecosystem functioning: a consensus of current knowledge. Ecol Monogr 75:3-55. https://doi.org/10. 1890/04-0922

Horsley TW, Bicknell JE, Lim BK, Ammerman LK (2015) Seed dispersal by frugivorous bats in Central Guyana and a description of previously unknown plant-animal interactions. Acta Chiropt 17:331336. https://doi.org/10.3161/15081109ACC2015.17.2.008

Isaacs R, Tuell J, Fiedler A, Gardiner M, Landis D (2009) Maximizing arthropod-mediated ecosystem services in agricultural landscapes: the role of native plants. Front Ecol Environ 7:196-203. https://doi. org/10.1890/080035 
Kemp J, López-Baucells A, Rocha R, Wangensteen OS, Andriatafika Z, Nair A, Cabeza M (2019) Bats as potential suppressors of multiple agricultural pests: a case study from Madagascar. Agric Ecosyst Environ 269:88-96. https://doi.org/10.1016/j.agee.2018.09.027

Kremen C (2005) Managing ecosystem services: what do we need to know about their ecology? Ecol Lett 8:468-479. https://doi.org/10. 1111/j.1461-0248.2005.00751.x

Kunz TH, de Torrez EB, Bauer D, Lobova T, Fleming TH (2011) Ecosystem services provided by bats. Ann N Y Acad Sci 1223:138. https://doi.org/10.1111/j.1749-6632.2011.06004.x

Lacoeuilhe A, Machon N, Julien JF, Kerbiriou C (2018) The relative effects of local and landscape characteristics of hedgerows on bats. Diversity 10:72. https://doi.org/10.3390/d10030072

Laurindo RS, Novaes RLM, Vizentin-Bugoni J, Gregorin R (2019) The effects of habitat loss on bat-fruit networks. Biodivers Conserv 28: 589-601. https://doi.org/10.1007/s10531-018-1676-x

Lobova T, Geiselman C, Mori S (2009) Seed dispersal by bats in the Neotropics. In: Memoirs of the New York Botanical Garden. New York Botanical Garden Press. The Bronx, New York

López-Hoffman L, Diffendorfer J, Wiederholt R, Bagstad KJ, Thogmartin WE, McCracken G, Medellin RL, Russell A, Semmens DJ (2017) Operationalizing the telecoupling framework for migratory species using the spatial subsidies approach to examine ecosystem services provided by Mexican free-tailed bats. Ecol Soc 22(4) https://www.ecologyandsociety.org/vol22/iss4/art23/

Maas B, Clough Y, Tscharntke T (2013) Bats and birds increase crop yield in tropical agroforestry landscapes. Ecol Lett 16:1480-1487. https://doi.org/10.1111/ele.12194

Maine J, Boyles JG (2015) Bats initiate vital agroecological interactions in corn. PNAS 112:12438-12443. https://doi.org/10.1073/pnas. 1505413112

Medellin RA, Wiederholt R, Lopez-Hoffman L (2017) Conservation relevance of bat caves for biodiversity and ecosystem services. Biol Conserv 211:45-50. https://doi.org/10.1016/j.biocon.2017.01.012

Méndez LE, Calle Z (2007) Árboles y arbustos de la cuenca media del río la Vieja, Guía de campo. CIPAV y CIEBREG. Cali, Colombia. 192 $\mathrm{p}$

Méndez LE, Calle Z (2010) Plantas de la Cuenca Media del Río La Vieja. Cali, Colombia. CIPAV y CIEBREG. $236 \mathrm{p}$

Muscarella R, Fleming TH (2007) The role of frugivorous bats in tropical forest succession. Biol Rev 82:573-590. https://doi.org/10.1111/j. 1469-185X.2007.00026.X

Olea-Wagner A, Lorenzo C, Naranjo E, Ortiz E, León-Paniagua L (2007) Diversidad de frutos que consumen tres especies de murciélagos (Chiroptera: Phyllostomidae) en la selva lacandona, Chiapas, México. Rev Mex Biodiv 78(1)

Olimpi EM, Philpott SM (2018) Agroecological farming practices promote bats. Agric Ecosyst Environ 265:282-291. https://doi.org/10. 1016/j.agee.2018.06.008

Oliveira MT, Silva JL, Cruz-Neto O, Borges LA, Girão LC, Tabarelli M, Lopes AV (2020) Urban green areas retain just a small fraction of tree reproductive diversity of the Atlantic forest. Urban For Urban Greening 54:126779. https://doi.org/10.1016/j.ufug.2020.126779

Ortegón-Martínez DA, Pérez-Torres J (2007) Estructura y composición del ensamblaje de murciélagos (Chiroptera) asociado a un cafetal con sombrío en la mesa de los santos (Santander). Actual Biol 29: 215-228

Park KJ (2015) Mitigating the impacts of agriculture on biodiversity: bats and their potential role as bioindicators. Mamm Biol 80:191-204. https://doi.org/10.1016/j.mambio.2014.10.004

Pattanayak S, Evan MD (1996) Valuing soil conservation benefits of agroforestry practices. Southeastern Center for Forest Economics Research, Research Triangle Park. NC. FPEI Working Paper No. $59.21 \mathrm{p}$

Pérez-Torres J, Sánchez C, Cortés N (2009) Murciélagos asociados a sistemas naturales y transformados en la Ecorregión del Eje
Cafetero. En: Valoración de la Biodiversidad en la Ecorregión del Eje Cafetero. CIEBREG. Pereira, Colombia, pp. 157-167

Perfecto I, Armbrecht I (2003) The coffee agroecosystems in the neotropics: combining ecological and economic goals. In: Tropical Agroecosystems (ed. Vandermeer, H.J). CRC Press, Boca Raton, USA, pp 159-194

Pla L, Casanoves F, Di Rienzo J (2012) Quantifying functional biodiversity. Springer Science \& Business Media

Raudsepp-Hearne C, Peterson GD, Bennett EM (2010) Ecosystem service bundles for analyzing tradeoffs in diverse landscapes. PNAS 107:5242-5247. https://doi.org/10.1073/pnas.0907284107

Rivas-Rojas E (2005) Diversity bats of dry forest and cocoa plantation. Lyona J Ecol Application 8:29-39

Rodríguez JM, Camargo JC, Niño J, Pineda AM, Arias LM, Echeverry M A, Miranda CL, (eds). (2009) Valoración de la Biodiversidad en la Ecorregión del Eje Cafetero. CIEBREG. Pereira, Colombia. $238 \mathrm{p}$

Rodríguez-San Pedro A, Chaperon P, Beltrán N, Allendes C, Ávila F (2018) Influence of agricultural management on bat activity and species richness in vineyards of Central Chile. J Mammal 99: 1495-1502. https://doi.org/10.1093/jmammal/gyy121

Saldaña-Vázquez RA, Ruiz-Sanchez E, Herrera-Alsina L, Schondube JE (2015) Digestive capacity predicts diet diversity in Neotropical frugivorous bats. J Anim Ecol 84:1396-1404. https://doi.org/10.1111/ 1365-2656.12383

Sánchez F (2017) Murciélagos de Villavicencio (Meta, Colombia): evaluación preliminar de su diversidad trófica y servicios ecosistémicos. Bol Cient Mus Hist 21:96-111

Santos-Barrera G, Urbina-Cardona J (2011) The role of the matrix-edge dynamics of amphibian conservation in tropical montane fragmented landscapes. Rev Mex Biodivers 82:679-687

Scanlon AT, Petit S, Tuiwawa M, Naikatini A (2014) High similarity between a bat-serviced plant assemblage and that used by humans. Biol Conserv 174:111-119. https://doi.org/10.1016/j.biocon.2014. 03.023

Sosa V, Hernández-Salazar E, Hernández-Conrique D, Castro-Luna A (2008) Murciélagos (Mammalia: Chiroptera). pp. 181-192. In: Manson, R., V. Hernández-Ortíz, S. Gallina \& K. Mehltreter (Eds.). Agroecosistemas Cafetaleros de Veracruz: Biodiversidad, Manejo y Conservación. Instituto de Ecología A. C. (INECOL). México

Starik N, Göttert T, Heitlinger E, Zeller U (2018) Bat community responses to structural habitat complexity resulting from management practices within different land use types - a case study from northeastern Germany. Acta Chiropt 20:387-405. https://doi.org/10. 3161/15081109ACC2018.20.2.010

Suarez A (2012) Transición hacia la Multifuncionalidad agrícola en la cuenca Barbas: Procesos agrícolas multifuncionales en fincas de Colombia. Editorial Académica Española. 66 pp. ISBN: 978-65902911-0

Syafiq M, Atiqah ARN, Ghazali A, Asmah S, Yahya MS, Aziz N et al (2016) Responses of tropical fruit bats to monoculture and polyculture farming in oil palm smallholdings. Acta Oecol 74:1118. https://doi.org/10.1016/j.actao.2016.06.005

Taylor PJ, Grass I, Alberts AJ, Joubert E, Tscharntke T (2018) Economic value of bat predation services-a review and new estimates from macadamia orchards. Ecosyst Serv 30:372-381. https://doi.org/10. 1016/j.ecoser.2017.11.015

Triplett S, Luck GW, Spooner P (2012) The importance of managing the costs and benefits of bird activity for agricultural sustainability. Int $\mathrm{J}$ Agric Sustain 10:268-288. https://doi.org/10.1080/14735903.2012. 700102

Vanitharani J (2014) Sustainable management of forest through ecosystem services of bats. Int Res J Biol Environ Sci 1:1-18 https://www. scrutinyjournals.com/articles?articleid $=78$

Wainger LA, King DM, Mack RN, Price EW, Maslin T (2010) Can the concept of ecosystem services be practically applied to improve 
natural resource management decisions? Ecol Econ 69:978-987. https://doi.org/10.1016/j.ecolecon.2009.12.011

Wanger TC, Darras K, Bumrungsri S, Tscharntke T, Klein AM (2014) Bat pest control contributes to food security in Thailand. Biol Conserv 171:220-223. https://doi.org/10.1016/j.biocon.2014.01. 030

Wiederholt R, Bagstad KJ, McCracken GF, Diffendorfer JE, Loomis JB, Semmens DJ et al (2017) Improving spatio-temporal benefit transfers for pest control by generalist predators in cotton in the southwestern US. Int J Biodivers Sci Ecosyst Serv Manag 13:27-39. https://doi.org/10.1080/21513732.2016.1240712

Winfree R, Bartomeus I, Cariveau DP (2011) Native pollinators in anthropogenic habitats. Annu Rev Ecol Evol Syst 42:1-22. https://doi. org/10.1146/annurev-ecolsys-102710-145042
Zhang W, Ricketts TH, Kremen C, Carney K, Swinton SM (2007) Ecosystem services and dis-services to agriculture. Ecol Econ 64: 253-260. https://doi.org/10.1016/j.ecolecon.2007.02.024

Znajda SK (2000) Conservación de hábitat, diversidad de aves y agroecosistemas de café en Costa Rica. Presentado En: Coloquio Internacional "Desarrollo sustentable, participación comunitaria y conservación de la biodiversidad en México y América Latina"

Zorita E (2003) Ponencia: Sistemas de producción ganaderos: situación actual y perspectivas. En: Libro blanco de la Agricultura y el desarrollo rural

Publisher's note Springer Nature remains neutral with regard to jurisdictional claims in published maps and institutional affiliations. 